\title{
Some Notes for Translating Vietnamese and English Sentences
}

\author{
Thanh Minh To \\ Faculty of Foreign Languages, Hoa Sen University, Ho Chi Minh City, Vietnam
}

\section{Email address:}

minhthanhto@gmail.com, thanh.tominh@hoasen.edu.vn

\section{To cite this article:}

Thanh Minh To. Some Notes for Translating Vietnamese and English Sentences. International Journal of Language and Linguistics. Vol. 7, No. 6, 2019, pp. 269-276. doi: 10.11648/j.ij11.20190706.14

Received: August 10, 2019; Accepted: September 5, 2019; Published: October 25, 2019

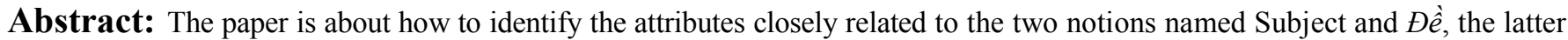
including the Topic and the Range Topic, as well as to find out how to translate the Vietnamese sentences the basic structure of which is the Topic-Comment structure into the English sentences the basic structure of which is the Subject-Predicate structure. The paper starts with a selected Vietnamese declarative which in its typical Topic-Comment structure with a succession of three Range Topics in the initial position in order to show the time and space in which whatever presented in the Comment occurs. The paper then presents, one after another, the two suggested translated versions in English: the former requires a Subject which doubles as Topic, which is 'you' in this case, in order to play the semantic role of "the Actor"; the latter is an inverted sentence in English, which is definitely equivalent in sense and better reflects the very Topic-Comment structure as well. Considerable attention has been paid to the distinction between the Topic and the Range Topic in the Vietnamese sentences in question. Such a distinction is crucial not only to widely perceiving what is called "meaning" but also to producing wellformed translated versions, either from English into Vietnamese or vice versa. After the theoretical points that are based basically on Functional Grammar are some notes for translating Vietnamese and English sentences. Hopefully, this contributes to drawing the attention of those who have practiced translating, and hopefully professional translators as well, to sophisticated issues in translation, both from and into the English language, which is part of the whole process of language learning.
\end{abstract}

Keywords: Subject, Topic, Subtopic, Comment, Minor Comment, Range Topic, Subject-Predicate Structure, Topic-Comment Structure

\section{Introduction}

It is still observed that students whose major is English at a university in Ho Chi Minh City, Vietnam, have translated the following Vietnamese declarative which begins with two or more Range Topics [1] into an English sentence without any Subject: Nowadays, having the green trees, the flavor of flowers, the sweet of fruits in all the country and... ; Nowadays, all over the country wherever saw the green trees, smell of flowers and of...

Below is my analysis of the translated version of the above mentioned Vietnamese sentence, suggested by a university teacher who is in charge of a course named VietnameseEnglish Translation:

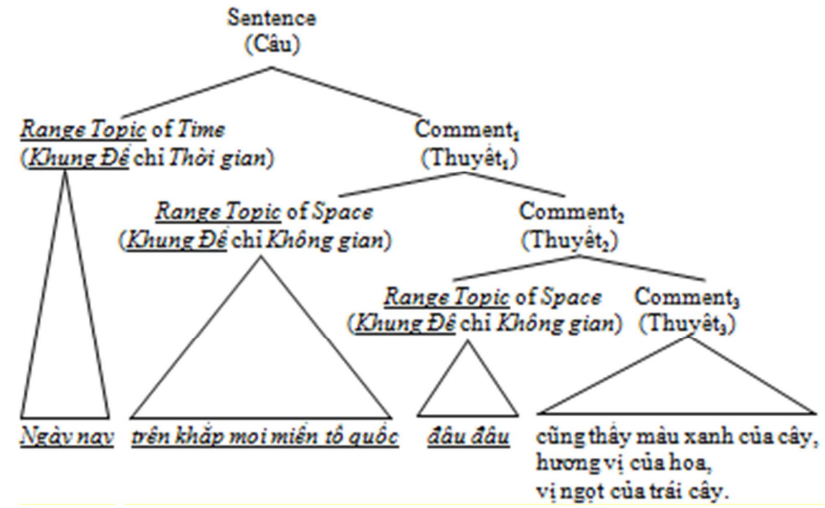

Figure 1. The Topic-Comment structure in a Vietnamese declarative with its three Range Topics sentence-initially. 


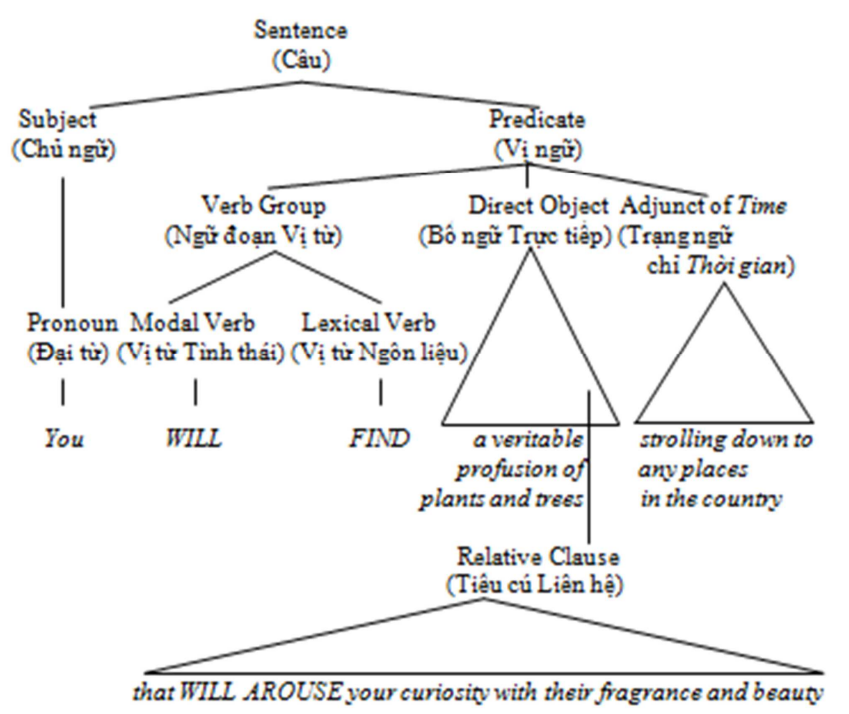

Figure 2. First translated version: the Subject-Predicate structure with a Subject which doubles as Topic sentence-initially.

While the given Vietnamese declarative is in its typical Topic-Comment structure with a succession of three Range Topics in the initial position in order to show the time and space in which whatever presented in the Comment occurs, its equivalent English sentence requires a Subject which doubles as Topic (abbreviated to S/T) [1], which is ' $y o u$ ' in this case, in order to play the semantic role of "the Actor". Obviously, to convey the same meaning, each of the two languages uses one or more than one means, as stated by $\mathrm{R}$. Jacobson [2]: languages basically differ not in what they can express but in what they must express.

Presumably, the over-mentioned suggested key fails to indicate the Topic-Comment structure of the original Vietnamese sentence in question and the teacher who has created the key did apply an intentional change and/ or unnecessary transposition instead of using the English inverted sentence, which is definitely equivalent in sense and better reflects the very Topic-Comment structure as well. That is the reason why I would like to propose another translated key for the Vietnamese sentence:

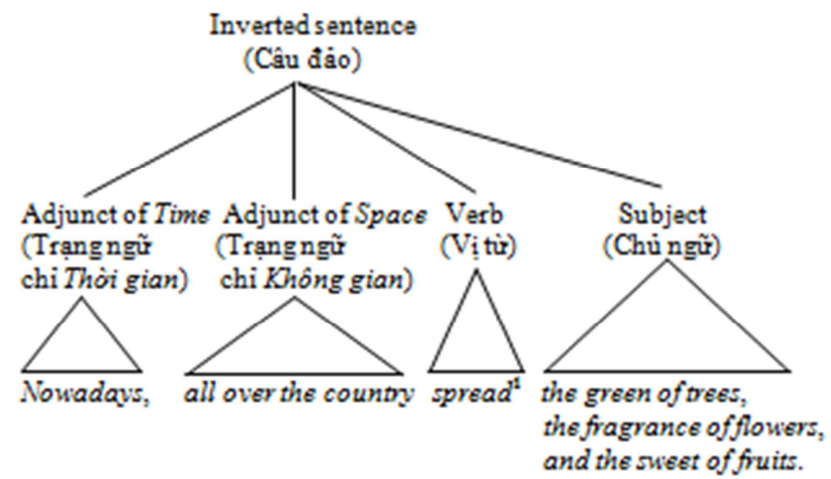

Figure 3. Second translated version: the Topic-Comment structure with its two Range Topics sentence-initially.

From the issues in my teaching practice at higher education in Vietnam, I have tried my best to enter the field of research, with the real hope that whatever has been found in that research will serve my permanent job as a life-long non-native teacher of English.

\section{Literature Review}

In oder to have the theoretical ground for the practice of translating sentences, mostly declarative sentences, from English to Vietnamese and from Vietnamese to English, the author of this paper has perceived and then developed the achievements of the book named The Vietnamese Functional Grammar. Volume one. Sentences in the Vietnamese Language by Cao Xuan Hao (chief author), Hoang Xuan Tam, Nguyen Van Bang and Bui Tat Tuom [1998], basing specifically on the following notions:

\subsection{The Topic-Comment Structure of the Vietnamese Sentence}

The syntactic structure of a sentence in the Vietnamese language corresponds basically to the structure of a proposition. It consists of two parts: the Topic (abbreviated to $\mathrm{T}$ ) and the Comment (abbreviated to C), corresponding respectively to the Subjectum và the Praedicatum of the structure of a proposition. The completeness of the Vietnamese sentence results from the fact that the sentence itself forms an utterance which has its own truth value as well as its illocutionary force, and which is percieved by the hearer as a well-formed speech act [3: 22-23]:

Table 1. Correspondence between the structure of a Vietnamese sentence and that of a proposition.

\begin{tabular}{|c|c|c|}
\hline (1a) & $\begin{array}{l}\text { Mẹ } \\
\text { 'Mom' }\end{array}$ & $\begin{array}{l}\text { đi Hà nội rồi. } \\
\text { 'go to Hanoi already' }\end{array}$ \\
\hline (1b) & $\begin{array}{l}\text { Năm nay } \\
\text { 'this year' }\end{array}$ & $\begin{array}{l}\text { mua it quá. } \\
\text { 'rains too rarely' }\end{array}$ \\
\hline (1c) & $\begin{array}{l}\text { Búc này } \\
\text { 'this picture' }\end{array}$ & $\begin{array}{l}\text { màu không đẹp. } \\
\text { 'color is not beautiful' }\end{array}$ \\
\hline (1d) & $\begin{array}{l}\text { Trò̀i MÀ mura } \\
\text { 'if it rains' }\end{array}$ & $\begin{array}{l}\text { THÌ ơ lại. } \\
\text { 'then stay' }\end{array}$ \\
\hline $\begin{array}{l}\text { Structure of a proposition: } \\
\text { Structure of a sentence: }\end{array}$ & $\begin{array}{l}\text { the Subjectum } \\
\text { the Topic }\end{array}$ & $\begin{array}{l}\text { the Praedicatum } \\
\text { the Comment }\end{array}$ \\
\hline
\end{tabular}

The order of the Topic preceding the Comment is normal in the vast majority of Vietnamese sentences. The opposite order is too rare to be found only in a small number of special circumstances. This is because the Topic expresses the Subjectum of a proposition, which is the starting point of an assertion.

\subsection{Topic}

\section{- Definition:}

In the Vietnamese language, the Topic is a semantic as well as a grammatical subject matter. Its status as a meaning component of a sentence is clarified via the following definition: "The Topic is the first immediate constituent of a sentence which indicates the scope of application of its second immediate constituent: the Comment." [3: 41]

- Classification: 
+ The Outer Topic [3: 41-42] is such an emphasized Topic that the hearer has to pay attention to before listening to the whole statement ... There is always a pause after the Outer Topic.

(2a) Cái ông Hùng ấy mà, ông ấy vùa chết tối hôm qua.

'As for Mr. Hung, he died yesterday evening.'

(2b) Anh Nam ấy à, tôi vìa gặp anh ấy ở trương xong.

'As for Nam, I've just seen him at school.'

(2c) Công việc u, thi tôi vẫn quan tâm đấy chư!!

'As for the job, I've really cared about it!'

The Outer Topic can stand by itself as an individual sentence, being separated from the syntactic structure of the sentence in question:

(2c') Công việc u? Thi tôi vẫn quan tâm đấy chư!

'The job? I've really cared about it!'

The Outer Topic can also occur as the tail of a sentence, or as a separate sentence following the sentence in question:

(3a) Anh có gặp ông ấy không, ông Văn ấy mà?

'Have you seen him, Mr Van?'

(3b) Anh có gặp ông ấy không? Ông Văn ấy mà?

'Have you seen him? Mr Van?'

+ The Inner Topic [3: 41]

The majority of the Topics in Vietnamese sentences are Inner Topics, which differ from Outer Topics in the fact that the former is included in the syntactic structure of the Vietnamese sentence while the latter is not. There is no pause after the Inner Topic, which consists of two subtypes:

1) The Topic is a sentence component which refers to whatever (either an individual, or a collection, or a state of affairs) being talked about.

2) The Range Topic (abbreviated to RangeT) is a sentence component which indicates the time, the space, the condition, or the situation in which whatever being mentioned in the Comment is valid.

The Topic and the Range Topic share the same function: identifying the scope of the application of the Comment; they differ basically in the properties of the thing in the former and those of the background in the latter.

Table 2. Topic vs. Range Topic sentence-initially.

\begin{tabular}{|c|c|c|c|}
\hline & Range Topic & Topic & Comment \\
\hline (4a) & & $\begin{array}{l}\text { Tình hình đó } \\
\text { 'That situation' }\end{array}$ & $\begin{array}{l}\text { đòi hỏi ta phải cố gắng. } \\
\text { 'requires our effort' }\end{array}$ \\
\hline (4b) & $\begin{array}{l}\text { Trong tình hinh đó } \\
\text { 'In that situation' }\end{array}$ & $\begin{array}{l}\text { Ta } \\
' w e '\end{array}$ & $\begin{array}{l}\text { phải cố gắng. } \\
\text { 'have to try our best' }\end{array}$ \\
\hline (4c) & $\begin{array}{l}\text { Trong tình hinh đó } \\
\text { 'In that situation' }\end{array}$ & $\begin{array}{l}\text { cấp trên } \\
\text { 'the superior' }\end{array}$ & $\begin{array}{l}\text { đòi hỏi ta phải cố gắng. } \\
\text { 'require our effort' }\end{array}$ \\
\hline
\end{tabular}

Distinction between the Topic and the Range Topic: thế in (5a) là the Range Topic, while thế in (5b) is the Topic [3:34].

(5a) Thế (RangeT of Condition) THÌ (C) tốt.

'If it is like this then it is good.'

(5b) Thế (T) LÀ (C) tốt.

'This is good.'

\subsection{The Topic's Influence on Co-referential Deletion}

It is because of such an influence that máy này ('this machine') does not appear in the following positions in the
Vietnamese sentence numbered (6):

- đặt mua máy này (direct object)

'order this machine';

- máy này (Topic) chạy tốt

'this machine run well';

- máy này (Topic) it hao xăng

'this machine consume less fuel';

- giá máy này (post-nominal modifier) rẻ

'price this machine be quite low';

- máy này (Topic) giá lại rẻ

'this machine price be quite low'.

(6) Máy này (T) $\perp$ (C) nhiều nơi đặt mua $\varnothing$ vì $\varnothing$ chạy tốt, $\varnothing$ it hao xăng, giá $\varnothing$ lại rẻ.

'This machine many places order $\varnothing$ because $\varnothing$ runs well, $\varnothing$ consumes less fuel, price $\varnothing$ is quite low'

The Topic's influence on co-referential deletion [3: 51] indicates that the Topic in Vietnamese declarative sentences is simmultaneously a syntactic component of the sentences. On the other hand, the Topic in the English language is only a subject matter of semantics. Quite often, the Subject doubles as the Topic (abbreviated to Subject/T) of English declarative sentences. The Subject which does not double as the Topic is the grammatical subject, also called the dummy subject, like it or there. Obviously, the section following either the Subject/T or the dummy subject is the Predicate which doubles as the Comment (abbreviated to Predicate/C).

\subsection{The Subtopic and the Minor Comment of an Embedded Clause}

When the Topic of the Vietnamese sentence is in the form of an embedded clause (and thus called the clausal Topic), the two immediate constituents of this clausal Topic are respectively called the subtopic (abbreviated to subT) and the minor comment (abbreviated to minorC) [3: 36; 73-77].

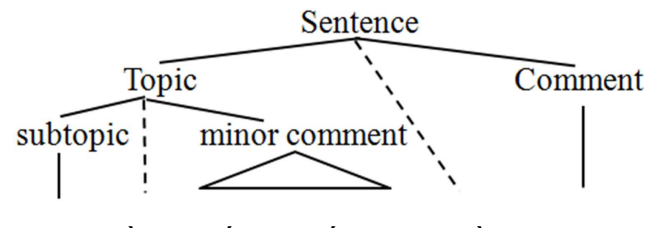

(7) Người MÀ đến thế THÌ thôi.

Below is the linear presentation of the Vietnamese sentence numbered (7) ${ }^{1}$ :

(7') Ngươi (subT) MÀ (minorC) đến thế (T) THİ (C) thôi.

'If a person who is like that then we have no other comment.'

And below is the linear presentation of a two-level complex sentence the Comment of which is an embedded clause, resulting in the clausal Comment:

(4b') Trong tình hình đó (RangeT of Situation) $\perp$ (C) ta (subT) \# (minorC) phải cố gắng.

'In that situation we have to try our best'

1 Notes: $\perp$ is the boundary between the Topic (T) and the Comment $(\mathrm{C})$; \# is the boundary between the subtopic (subT) and the minor comment minorC; $\mid$ is the boundary between the Subject which doubles as the Topic (Subject/T) and the Predicate which doubles as the Comment (Predicate/C); $\varnothing$ means "empty". 
(6’) Giá $(\mathrm{T}) \perp(\mathrm{C})$ máy này (subT) \# (minorC) rẻ.

'Price this machine be quite low'

\subsection{The Optionality of the Topic in Vietnamese Sentences}

According to $\mathrm{Ch}$. $\mathrm{Li}$ và $\mathrm{S}$. Thompson, the Subject is always "an argument of a predicative constituent" [4], while the Topic "is not determined by the verb ... the speaker still has considerable freedom in choosing a topic noun phrase regardless of what the verb is" [4:463].

(8a) Cây này $(\mathrm{T}) \perp(\mathrm{C})$ hoa (subT) \# (minorC) rất đẹp.

'This tree flowers be very beautiful'

(8b) Ông h́y $(\mathrm{T}) \perp$ (C) tóc (subT) \# (minorC) bac rồi.

'He hair be white already'

(8c) Búc tranh đó (T) $\perp$ (C) bố cục (subT) \# (minorC) không chặt chẽ.

'That picture layout be not well-balanced'

(8d) Hôm (RangeT of Time) THÌ (C) anh Long (subT) \# (minorC) đi xe đạp,

hôm (RangeT of Time) THI (C) anh Long (subT) \# (minorC) đi xe máy.

'One day Long ride a bicycle, the other day Long ride a motorbike'

(8e) Chố nguò̀i ta (subT) \# (minorC) chua xây nhà (RangeT of Space), (C) chúng tôi (subT) \# (minorC) sẽ trồng rau.

'Where people not yet build houses, we will plant vegetables'

The Topic or the Range Topic of Vietnamese sentences is not only in the form of a noun phrase, as mentioned above by Ch. Li và $S$. Thompson [4]:

(9a) Nói (T) THÌ (C) bà Ba (subT) \# (minorC) nói rất nhiè̀u.

'Talk Mrs. Ba talk a lot'

(9b) Nếu nói về con ngưòi (RangeT of Condition) THÌ (C) đó (subT) \# (minorC) LÀ vốn quý nhất.

'If talk about human beings then those be the most precious capital'

\subsection{The Markedness of the Topic in English Sentences}

There are cases in which the Topic is marked in the English language, i.e. the Topic does not double as the Subject of a sentence, as in (10a) and (10b); on the contrary, the Topic is not marked at all in the Vietnamese language, as observed in the suggested translated versions of the two given English sentences:

(10a) A socialist (T) $\perp$ (C) I (subT) \# (minorC) am and a socialist $(\mathrm{T}) \perp(\mathrm{C}) I$ (subT) \# (minorC) shall always be.

'Một đảng viên xã hội $(\mathrm{T}) \perp$ (C) tôi (subT) \# (minorC) là $n h u$ vậy và một đảng viên xã hộ $\mathrm{T}) \perp(\mathrm{C})$ tôi (subT) \# (minorC) sẽ mãi mãi là nhu vâyy.'

(10b) David (T) $\perp$ (C) he (subT) \# (minorC) showed with a sling on his shoulder.

'Búc tuọng của David (T) THÌ (C) ông (subT) \# (minorC) tac có tua ờ vai.'

This does not mean that the English language does not have the Topic which is unmarked, i.e. the cases in which the
Subject doubles as the Topic of the sentence:

(10a') I (Subject/T) | (Predicate/C) am a socialist and I (Subject/T) | (Predicate/C) shall always be a socialist.

'Tôi là một đảng viên xã hội và tôi sẽ mãi mãi là một đảng viên xã họi.'

(10b') He (Subject/T) | (Predicate/C) showed David with a sling on his shoulder.

'Ông tạc bức tượng David có tua ở vai.'

\subsection{The Contrastiveness of the Topic in English Sentences}

The Topic in English sentences is marked and simultaneously contrasts with either another Topic or a certain argument in its preceding sentence or the embedded clause of this sentence:

(11a) Other books (T) $\perp$ (C) I (subT) \# (minorC) haven't read but this book $(\mathrm{T}) \perp(\mathrm{C}) I$ (subT) \# (minorC) have read.

'Nhũng quyển khác (T) THİ (C) tôi (subT) \# (minorC) chua đọc còn quyển này $(\mathrm{T})$ THÌ $(\mathrm{C})$ tôi (subT) \# (minorC) đọc rồi.'

(11b) (Most of the examples come from the texts, but) this one $(\mathrm{T}) \perp(\mathrm{C}) I$ (subT) \# (minorC) invented.

'(Hầu hết các ví du là trong sách, riêng) ví du này (T) THÌ (C) tôi I (subT) \# (minorC) tụ nghĩ ra.'

(11c) (I find I get on with his wife very well, but) him (T) $\perp$ (C) I (subT) \# (minorC) can't bear.

'(Tôi thấy vợ hắn THÌ dế chịu, còn) hắn (T) THÌ (C) tôi I (subT) \# (minorC) không thể chịu nổi.'

The above-mentioned illustrations help to confirm that, in English sentences, topicalization is a signal of the SubjectPredicate structure in which a certain argument of the predicative constituent, i.e. the verb phrase, of a sentence, is inverted to its initial position to play the role of the Topic, which is obviously marked. On the contrary, the TopicComment structure is the basic structure of Vietnamese sentences because contrastiveness is not the inhererent property of the Topic or the Range Topic of the Vietnamese sentences.

\subsection{Topic-Comment Marker vs. Subtopic-minor Comment Marker}

THİ, LÀ and MÀ coordinate with each other to create layers of the Topic-Comment structure in a Vietnamese sentence and its embedded clause. THI helps to identify the Topic and the Comment, especially where the inherent properties of the Topic and/ or those of the Comment have not yet clarified their status by themselves. LÀ has a lot of functions in Vietnamese sentences, including the function of marking the boundary between the Topic and the Comment. MÀ also has a lot of functions in Vietnamese sentences; it especially marks the boundary between the subtopic and the minor comment of the embedded clause in a Vietnamese sentence, especially of the clausal Topic.

The distinction between THİ, LÀ and MÀ have been described in detail [3: 25-38]; thanks to these descriptions, the author of this paper has done research on some notes for translating Vietnamese and English sentences. 


\subsection{Topic-Comment Structure vs. Subject-Predicate Structure}

On the one hand, the Topic-Comment structure clearly corresponds to the structure of a proposition: the Topic và the Comment correspond respectively to the Subjectum và the Praedicatum; on the other hand, the Subject-Predicate structure separates from the structure of a proposition: the grammatical subject of an English sentence need not to express any sense, i.e. it does not need to play any semantic role, because it can be a grammtical means only. It is possible to consider the English sentences the Subject of which doubles as the Topic as the ones that have the TopicComment structure, and the English sentences the Subject of which does not double as the Topic as the ones that have the Subject-Predicate structure.

\section{Translating Vietnamese and English Sentences}

\subsection{Ways to Translate Vietnamese Sentences with a Double Topic}

There are two ways to translate the Vietnamese sentence with a double Topic [6: 3].

The first way:

Combine the Topic of the Vietnamese sentence with the subtopic of its embedded clause to produce the Subject which doubles as the Topic of the English sentence which is considered as the equivalent translated version of the Vietnamese sentence in question:

(12a) Bọn họ (T) THİ (minorC) không ai (subT) \# (minorC) $Đ \hat{E} N$ cá.

(12b) 'None of them $\left(\right.$ Subject/T) | (Predicate/C) CAME. ${ }^{2}$

The second way:

Either keep the Range Topic of the Vietnamese sentence or change it to an Outer Topic beginning with for ('còn về/ còn nhu về'), about ('về'), hay as far as ... is concerned ('vêे/ nói

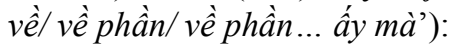

(13a) Trong vu hỏa hoạn ấy (RangeT of Space) $\perp$ (C) lính cúu hỏa (subT) \# (minorC) ĐẾN sóm.

(13b) 'In that fire (RangeT of Space) ${ }^{3}$, the fire-brigade (subT) \# (minorC) ARRIVED early.'

(13c) 'As for that fire (Outer Topic), the fire-brigade (subT) \# (minorC) ARRIVED early.'

Sometimes the two ways are both correct:

(14a) Cây này (T) $\perp$ (C) lá (subT) \# (minorC) quá lón.

(14b) 'The leaves of this tree (Subject/T)| (Predicate/C) ARE too big.'

(14c) 'As for this tree (Outer Topic), (C) the leaves (subT)

2 Below are two other translated versions of (12b):

(12c) 'Trong bọn ho (RangeT of Situation) $\perp$ (C) không ai (subT) \# (minorC) ĐẾN cả.'

(12d) 'Không ai trong bọn họ $(\mathrm{T}) \perp(\mathrm{C}) Đ \hat{E} N$ cả.'

3 Below is another translated version of (13a):

(13d) 'At that fire (RangeT of Space), (C) the fire-brigade (subT) \# (minorC) ARRIVED early.'
\# (minorC) ARE too big.'

Quite often, only one of the two ways is considered as correct. Therefore, knowing how to distinguish the Topic from the Range Topic in Vietnamese sentences is crucial, not only for the recognition of the lexical meaning of the sentences in question but also for their satisfactory translated versions. Try to translate (16a) with the Topic 'vải này' and (18a) with the Range Topic 'sang năm':

(15a) Vải này $(\mathrm{T}) \mathrm{THÌ}(\mathrm{C})$ thật ré.

(15b) 'This cloth (Subject/T) | (Predicate/C) IS really cheap.'

(16a) Vải này MÀ năm ngoái ở Huế môi mét giá chỉ năm ngàn LÀ cùng (T) THÌ (C) thật rẻ.

(16b) 'This cloth the price of which WAS only five thousand Vietnam dồng per meter in Huế last year (Subject/T)| (Predicate/C) IS really cheap.'

(17a) Sang năm (RangeT) THÌ (C) sống được đấy.

(17b) 'We (Subject/T) | (Predicate/C) CAN MANAGE to earn our bread next year.'

(18a) Sang năm MÀ ở Vinh gạo mỗi tạ giá 200 ngàn LÀ tối đa, ở đây hàng tuần tụi tôi chủ nhật nào cũng mỗi người một xe tải làm mấy chuyến (RangeT) THÌ (C) cũng sống được đấy.

(18b) 'Next year if rice COSTS a maximum of 200 thousand a quintal in Vinh and if we DO a few times every Sunday, each driving a truck (RangeT), (C) we (subT) \# (minorC) CAN MANAGE to earn our bread.'

\subsection{Ways to Make an Emphasis in Vietnamese and in English}

In Vietnamese sentences, "the emphasis has been done by using LÀ to mark the boundary between the Topic and the Comment, with or without the repetition of the Topic" [3: 32]. In their equivalent English sentences, such an emphasis has been done by either an adverb of degree like very in (19$20 \mathrm{~b}$ ), or the repetition of this adverb, resulting in very very in (21b); both cases being accompanied by the adverb indeed. It is interesting to identify the possible repetition of the Topic in Vietnamese and that of an adverb of degree, like very, in English. In other words, the means of emphasizing occurs in the Topic or right at the Topic-Comment boundary of the Vietnamese sentence in question; the emphasizing means occurs in the Predicate which doubles as the Comment of the equivalent English sentence:

(19a) Anh (T) $\perp$ (C) tệ lắm.

(19b) 'You (Subject/T) | (Predicate/C) ARE very bad.'

(20a) Anh (T) LÀ (C) tẹ lắm.

(20b) 'You (Subject/T) | (Predicate/C) ARE indeed very bad.'

(21a) Anh (T) LÀ (C) anh (subT) \# (minorC) tệ lắm.

(21b) 'You (Subject/T) | (Predicate/C) ARE indeed very very bad.'

\subsection{The Distinction Between LÀ and THİ}

Although they both mark the Topic-Comment boundary in Vietnamese sentences, LÀ and THÌ convey different senses 
and thus have to be translated differently in English. The repetition of the Topic in (22a) with LÀ "aims at emphasizing the meaning of the whole sentence, actually highlighting the Comment more than the Topic, but not comparing or contrasting with any other idea or another Comment" [3: 32]. The repetition of the Topic in (23a) with THI "aims at marking the Topic of the sentence and including a comparing or contrasting implication" [5: 416]. The sentence (23a) means that 'other people may prefer other authors whereas I only like to read Nam Cao'. Such a distinction is also found out in (24a) and (25a). It is the property of being marked of the Range Topic that makes it quite satisfactory to be the first and foremost choice to translate $(23 a)$ và $(25 a)$ :

(22a) Tôi (T) LÀ (C) tôi (subT) \# (minorC) chỉ THÍCH đọc Nam Cao.

(22b) 'I (Subject/T) | (Predicate/C) only LIKE to read Nam Cao.'

(23a) Tôi (T) THİ (C) tôi (subT) \# (minorC) chi THÍCH doc Nam Cao.

(23b) 'As for me (RangeT), (T) I (subT) \# (minorC) only LIKE to read Nam Cao.'

(24a) Bài báo này (T) LÀ (C) hay. ${ }^{4}$

(24b) 'This article (Subject/T) | (Predicate/C) IS interesting.'

(25a) Bài báo này (T) THÌ (C) hay.

(25b) 'As for this article (RangeT), (C) it (subT) \# (minorC) IS interesting.'

\subsection{The Co-referential Deletion in Vietnamese Sentences}

If a succession of sentences all talk about one and the same person or thing, i.e these sentences have co-reference, then the co-referential deletion, which is preferred in the Vietnamese language with its typical Topic-Comment structure, allows to omit Binh - the Actor of a series of actions encoded by dậy trua ('get up late'), đi họ trễ ('go to school late'), tìm auoòng trốn tránh ('refuse to do the chores') and chi thich choi bòi ('only like to play') in (26a). On the contrary, the Subject-Predicate structure of the equivalent English sentences requires to encode the Actor of these actions in (26b), replacing the proper noun 'Binh' by the pronoun ' $h e$ ':

(26a) Bính LÀ một học trò luời biếng. Sáng ngày $\varnothing D A ̣ Y$ trua, nên $\varnothing$ ĐI học trễ, mà tiếng rằng $\varnothing$ ĐI họ, nhưng chẳng mấy khi nó THUỘC bài và LÀM đủ bài. Khi nó ở nhà cha me sai làm việc gì THÌ $\varnothing$ tìm đường trốn tránh. Cả ngày $\varnothing$ chi THÍCH choi bò̀i lang thang ở ngoài đưòng, ngoài ngõ.

(26b) 'Binh IS a lazy pupil. Every morning, he GOES to school late because he GETS UP late. At school, he seldom KNOWS his lessons and DOES not DO all his exercises. At home, he REFUSES to do the chores when his parents tell him. All day long, he only LIKES to play and wander on the streets.'

4 Another version of the Vietnamese sentence (24a) is the following (24a'):

(24a') Bài báo này $(\mathrm{T}) \perp(\mathrm{C})$ hay.

'This article (Subject/T) | (Predicate/C) IS interesting.'

\subsection{The Co-referential Deletion in Vietnamese Folk Songs or Proverbs}

In Vietnamese folk songs or proverbs - ways of expressions that are quite short and really condensed, the coreferential deletion acts even more strongly and thus allows to omit tô $i$ (' $I$ ') - the Actor of the three actions encoded by ra đúng bò ao ('come out to stand by the pond'), trông cá ('look down at the fish') và trông sao ('look up to the stars') in (27a). On the contrary, the Subject-Predicate structure of the so-called English sentences requires encode the Actor of these actions in (27b), resulting in the repetition of the pronoun ' $I$ ':

(27a) Đêm qua (RangeT of Time) $\perp$ (C) $\varnothing R A$ đúng bò̀ ao

$\varnothing$ TRÔNG cá, cá LăN

$\varnothing$ TRÔNG sao, sao MÒ.

(27b) 'Last night I CAME out to stand by the pond.

If I LOOKED down at the fish, they DIVED;

if I LOOKED up to the stars, they FADED.'

\subsection{The Required Occurrence of the English Verb Phrase Predicate}

The Topic-Comment structure of Vietnamese sentences accepts only one word, which is not necessarily a verb, to be the Comment while the Subject-Predicate structure of their equivalent English sentences requires to encode the predicative constituent by a verb, even when this verb is relatively meaningless and just stands as a way of connecting the noun phrase Subject with the verb phrase Predicate:

(28a) Trước $\left(\mathrm{T}_{1}\right) \perp\left(\mathrm{C}_{1}\right)$ KHÁC, bây giờ $\left(\mathrm{T}_{2}\right) \perp\left(\mathrm{C}_{2}\right)$ KHÁC.

(28b) 'Nowadays (Subject/T)। (Predicate/C) IS different from the past.'

(28c) 'Things (Subject/T) | (Predicate/C) AREN'T like they WERE before.'

(28d) 'The times (Subject/T) | (Predicate/C) HAVE CHANGED.'

\subsection{The Required Occurrence of the English Noun Phrase Subject}

The Subject-Predicate structure of English sentences requires to encode the Actors of chua tó ("know nothing about it') và those of đã hay ('have already mastered it') to be the Subject which doubles as the Topic of the two clauses of the English sentence (29b); the equivalent Vietnamese sentence (29a) sees nobody to be the Actors of these acts, due to the Topic-Comment structure of Vietnamese sentences:

(29a) Trong nhà (Range $\mathrm{T}_{1}$ of Space) $\perp\left(\mathrm{C}_{1}\right) \varnothing$ chura TỎ, ngoài ngõ (Range $\mathrm{T}_{2}$ of Space $) \perp\left(\mathrm{C}_{2}\right) \varnothing$ đã $H A Y$.

(29b) 'While those from this family (Subject/T) । (Predicate/C) KNOW nothing about it, the outsiders (Subject/T) | (Predicate/C) HAVE already MASTERED it.'

\subsection{The Privileged Occurrence of the Vietnamese Range Topic of Time}

The Topic-Comment structure of Vietnamese sentences provides the Range Topic of Time with some privilege. Such 
a privilege does not exist in the Subject-Predicate structure of English sentences the prominent initial position of which is normally occupied by the Subject which doubles as the Topic. Accordingly, it is quite probable to convert respectively yesterday and now - the Adverbial of Time in the final position of the two English sentences named (30a) and (31a), into the Range Topic of Time hôm qua and bây giò in the initial position of the two equivalent Vietnamese sentences named (30b) and (31b):

(30a) They (Subject/T) | (Predicate/C) COME here yesterday (Adverbial of Time).'

(30b) 'Hôm qua (RangeT of Time) $\perp$ (C) ho (subT) \# (minorC) ĐẾN đây.'

(31a) [There'S the school bell.] I (Subject/T) | (Predicate/C) must GO now (Adverbial of Time).

(31b) '[Đấy LÀ chuông truòng.] Bây giờ (RangeT of Time $) \perp(\mathrm{C})$ tôi (subT) \# (minorC) phải ĐI.'

Thus, any translator is supposed to do the opposite whenever he/ she translates Hôm nay tôi ở nhà or Hai ngày nũa cha me tôi mói đến, resulting in the unmarked English sentences named (32b) and (33b-c):

(32a) Hôm nay (RangeT of Time) $\perp$ (C) tôi (subT) \# (minorC) Ở nhà.

(32b) 'I (Subject/T) | (Predicate/C) AM home today (Adverbial of Time).'

(33a) Hai ngày nũa (RangeT of Time) $\perp$ (C) cha mẹ tôi (subT) \# (minorC) mói ĐÉ́N.

(33b) 'My parents (Subject/T) | (Predicate/C) will COME in two days (Adverbial of Time).'

(33c) 'My parents (Subject/T) | (Predicate/C) won't COME until the day after tomorrow (Adverbial of Time).'

In addition, it is necessary to distinguish hom nay as the Range Topic of Time in the above-mentioned (32a) from hôm nay as the Topic in the following (34a):

(34a) Hôm nay (T) LÀ (C) ngày chủ nhật.

(34b) 'Today (Subject/T) | (Predicate/C) IS Sunday.'

The two sentences called $(34 \mathrm{a}-\mathrm{b})$ indicate the close similarity in their structure whereas hom qua as the Range Topic of Time in the Vietnamese sentence named (35a) and yesterday as the Adverbial of Time in the English sentence named (35b) share almost nothing in common: the former occurs in the typical Topic-Comment structure of the Vietnamese sentence; the latter occurs in the SubjectPredicate structure of the English sentence. Also distinguish today as the Subject which doubles as the Topic in the abovementioned (34b) from today as the Range Topic of Time in the second clause of the following sentence named (35b):

(35a) Hôm qua (RangeT of Time) $\perp$ (C) tôi (subT) \# (minorC) ĐI làm

còn hôm nay (RangeT of Time) $\perp$ (C) tôi (cđ) \# (t) Ỏ nhà.

(35b) ' $I$ (Subject/T) | (Predicate/C) WENT to school yesterday (Adverbial of Time),

but today (RangeT of Time) $\perp$ (C) I (subT) \# (minorC) AM home.'

\subsection{The Obligatory vs. The Optional THİ or LÀ}

Cao Xuan Hao [5: 414] distinguishes (36a-b) from (37a-b): the former require while the latter do not require the occurrence of THİ or LÀ": when "the two immediate constituents of a Vietnamese sentence look almost alike, the relationship between the two immediate constituents is not clear enough without the occurrence of THİ or LÀ as the marker of the boundary between the Topic and the Comment". The process of translating from Vietnamese to English requires the appropriate attention paid to the fact that the Range Topic of Time in (37a-b) has been translated into an adverbial, nominal or prepositional phrase while the Range Topic of Time, or of Condition, in (36a-b) has an English finite clause as its equivalent translated form:

(36a) Tạnh mua LÀ/ THÌ tôi ĐI.

'If / When it STOPS raining, I'M LEAVING.'

(36b) Đến giò̀ LÀ/ THÌ tôi ĐI.

'When it IS time, I'M LEAVING.'

(37a) Lát nũa (LÀ/ THÌ) tôi ĐI.

'I'M LEAVING soon/ in a few more minutes.'

(37b) Sáng mai/ Sáu giò̀ (LÀ/ THÌ) tôi ĐI.

'I'M LEAVING tomorrow morning/ at six o 'clock.'

Similarly, it is necessary to change the Range Topic at the beginning of the Vietnamese sentences named (38a-b) into the Adverbial of Time at the end of their equivalent English sentences:

(38a) Tròi sáng LÀ/ THÌ tôi ĐI.

'I'M LEAVING at dawn/ at daybreak.'

(38b) Ăn xong LÀ/ THÌ tôi ĐI.

'I'M LEAVING after lunch/ after diner.'

\subsection{The Distinction Between 'Bao giò̀' đi' and 'đi Bao giò̀'}

'Bao giò' (RangeT of Time) $\perp$ (C) $Đ I$ ', which is the TopicComment structure in (39a), is distinguished from ' $Đ I$ bao giơ', which is a phrase including the verb ' $d i$ ' and the adverbial 'bao giơ' in (39b) [5]:

(39a) Bao giò (RangeT of Time) $\perp$ (C) $\varnothing$ (cd) \# (t) $Đ I$ ? Mai (RangeT of Time) $\perp$ (C) $\varnothing$ (cđ) \# (t) $Đ I$.

'When ARE you GOING?' - 'I'M LEAVING tommorrow.'

(39b) Anh (T) $\perp$ (C) ĐI bao giờ? - Tôi (T) $\perp$ (C) ĐI hôm qua/ vào lúc sáu giò.

'When DID you GO?' - 'I LEFT yesterday/ at six o'clock.'

The past in the question (39b) and its reply results from "the givenness" of the state of affairs expressed by the Vietnamese verb ' $d i$ ' whereas "the adverbial 'bao gio', states what is being asked about" [5: 411-412]. In this case, word order is conditioned by "communicative dynamism" [7]: the verb ' $d i$ ' the communicative dynamism of which is low, because it conveys the given information and thus occurs before the adverbial 'bao giò', which conveys the new information and thus is definitely the focus of the reply.

The future in the question (39a) and its reply results from "the conditional meaning (as an assumption) of the Range Topic" và "the sense of being undone of the Comment" [5: 417] in the predicted reply. Mai (môt) ('tomorrow'/ 'the day after tomorrow'), tám giờ ('at eight o'clock'), lát nũa ('in a short/ little while'), sang năm ('next year'), chiều (tối) ('in the evening/ at night') and 'almost all of the adverbial of point of time at the beginning of the reply to the question 
'bao giò' đi' cannot be shifted to the end of the reply", as proved by (40a'-e'):

(40a) Mai (mốt) tôi ĐI. (40a') *Tôi ĐI mai mốt.

'Tomorrow/ The day after tomorrow I'M LEAVING.'

(40b) Chiều (tối) tôi ĐI. (40b') *Tôi ĐI chiều (tối).

'In the evening/ At night I'M LEAVING.'

(40c) Sang năm tôi ĐI. (40c') *Tôi ĐI sang năm.

'Next year I'M LEAVING.'

(40d) Tám giờ tôi ĐI. (40d') *Tôi ĐI tám giò̀.

'At eight o 'clock I'M LEAVING.'

(40e) Lát nũa tôi ĐI. (40e') *Tôi ĐI lát nũa

'In a short/ little while I'M LEAVING.'

"Communicative dynamism", i.e the contrast between the new and the given, determines the word order of the two Vietnamese questions named (41a-b) and their replies. This does not occur in their equivalent English sentences, where the deletion of the given, not the final position of the sentence, helps to highlight the new information. It has been proved that word order acts more strongly in the Vietnamese language than in the English language, and that, unlike Vietnamese, English uses deletion, not word order, to contrast the given information with the new information:

(41a) Anh VỀ khi nào? - Tôi VỂ hôm qua.

'When DID you COME home?'

- '(I CAME home) Yesterday.'

(41b) Hôm qua anh ĐI đâu? - Hôm qua tôi VỀ nhà.

'Where DID you GO yesterday?'

- 'I CAME home (yesterday).'

\section{Conclusion}

This paper aims at finding out ways of translating the Vietnamese sentences the basic structure of which is the Topic-Comment structure into the English sentences the basic structure of which is the Subject-Predicate structure. Considerable attention has been paid to the distinction between the Topic and the Range Topic in the Vietnamese sentences in question. Such a distinction is crucial not only to widely perceiving what is called "meaning" but also to producing well-formed translated versions, either from English into Vietnamese or vice versa. This contributes to drawing the attention of those who have practiced translating, and hopefully professional translators as well, to sophisticated issues in translation, both from and into the English language, which is part of the whole process of language learning.

\section{References}

[1] Cao Xuan Hao (2004), Tiếng Việt: Sơ thảo ngữ pháp chức năng. Quyển 1 (The Vietnamese Language: A Rough Draft on Functional Grammar. Volume one) ( $2^{\text {nd }}$ ed.), Hanoi: Social Sciences Press.

[2] Jacobson, R. (2000). On linguistic aspects of translation. In: L. Venuti (Ed.), The translation studies reader: 113-118, London/New York: Routledge.

[3] Cao Xuan Hao (chief author), Hoang Xuan Tam, Nguyen Van Bang and Bui Tat Tuom (1998), Ngữ pháp chức năng tiếng Việt. Quyển 1. Câu trong tiếng Việt (The Vietnamese Functional Grammar. Volume one. Sentences in the Vietnamese Language) ( $2^{\text {nd }}$ ed.), Hanoi: Education Press.

[4] Li, Ch. \& Thompson, S. (1976), Subject and topic: A new typology of language. In: Ch. Li (Ed.), Subject and Topic: 457489, New York: Academic Press.

[5] Cao Xuan Hao (1998), Tiếng Việt: Mấy vấn đề ngữ âm, ngữ pháp, ngũ̃ nghĩa (The Vietnamese Language: A number of Phonetic, Grammatical and Semantic Issues), Hanoi: Education Press.

[6] Dyvik, H. J. J. (1984), Subject or Topic in Vietnamese. Bergen: University of Bergen.

[7] Firbas, J. (1971). On the concept of communicative dynamism in the theory of Functional Sentence Perspective. Brno Studies in English 7: 12-47. 